years ago in what remains of the Dover Priory, established about I I3o. The magnificent Norman refectory will serve as the reception room and ticket office. The College is only about three minutes' walk from the Priory Station (L.C.D. Railway), and about as far from the Town Hall. Two of the Sections (anthropology and geography) will meet in a part of the town somewhat more remote from the reception room.

There will be no lack of entertainment of a public character. The General Commanding the South Eastern District (Sir Leslie Rundle) will give a garden party a the Castle ; the Council, head-master and assistantmasters of Dover College will give another in the College grounds. The Mayor (Sir William Crundall) will give a conversazione, and will also give a reception one afternoon at the Dover Athletic Grounds, when there will be an exhibition and contest of motor cars from all parts of Europe and America.

The smoking concert, which was so successful a feature of the Bristol meeting last year, will be repeated. There will also be a military tattoo by torchlight on the sea front one evening, with music by the massed bands of the garrison.

The visit of the French Association is to take place on Saturday, September I6. The members will arrive early, and, after a light repast at the Lord Warden Hotel, will assemble at the Town Hall, when addresses of welcome will be given. An adjournment will then be made to the various Sections, which will meet on Saturday this year, though that day is generally an "off-day." In many Sections the presidents will reserve their presidential addresses for this occasion, so as to give the French guests a chance of being present. There will be a luncheon afterwards in a marquee in the College grounds. In the afternoon, parties will visit the Castle and other objects of interest in Dover. There may be opportunity for a visit to Canterbury.

On Sunday there will be special services in most of the churches and chapels of Dover, whilst those who care to go further afield can take advantage of the arrangements made by Dean Farrar, of Canterbury, one of the vice-presidents of the Association this year, for there will be special services in the Cathedral, with well-known preachers, and an organ recital in the afternoon. The Canterbury Museum, which owes much to the munificence of its Hon. Curator, Mr. Bennett Goldney, a most useful member of the Dover Local Committee, will be open to members of the Association on Sunday afternoon.

The return visit of the British Association to the French will take place on Thursday, September $2 \mathrm{I}$. The details are not finally settled, but there will be a réunion with addresses, a luncheon, the unveiling of a plaque to the poet Campbell, who lived at Boulogne for some time. A statue to the French man of science, Duchesne, will also be unveiled. It is intended to start from Boulogne on the five days' excursion through the most interesting towns of Northern France and Belgium. The civic authorities in each town have very cordially responded to the efforts of the French and the Belgian consuls in Dover, and have promised to do all in their power to make the five days' excursion a great success.

Amongst the scientific men from the Continent, the United States and Canada, who have already accepted the invitation of the Local Committee, may be mentioned Profs. Dwelshauvers-Dery, Fittig, Gobert, Julin, Kronecker, Calmette, Chappuis, Barker, Carl Barus, SurgeonGeneral Billings, Profs. Bovey, Campbell, Scott, Thurston, and Van Rijckevorsel.

From what has been stated, it will be evident that those members of the Association who visit Dover will have no cause to be dissatisfied with the programme before them. W. H. Pendlebury.

\section{THE VOLTA CENTENARY EXHIBITION AT} COMO.

I $\mathrm{N}$ this age of electricity it is difficult to realise that only a hundred years have elapsed since the first electric current was produced by chemical means. The birthplace of Alessandro Volta has paid a fitting tribute to the pioneer of electrical science by holding an exhibition in commemoration of the discovery of the pile which bears the name of its inventor.

The Como Exhibition, which was opened on May zo, occupies a tract of land bordering on the Lake of Como, its natural surroundings harmonising well with the artistic arrangement of the buildings and exhibits. One section is devoted to electricity, another to the silk industries of Lombardy, while a small collection of pictures, church vestments, \&c., forms a minor feature.

International Congresses of electricians and of telegraphists have been organised at Como. At the latter Congress, which was held on May $3 \mathrm{I}$, an inaugural address was given by Di San Giuliano, and a competition between professional telegraphists took place.

In the electric exhibits, applied electricity occupies, as might be expected, the most prominent place. All the machines in the exhibition, including the silk-spinning and weaving machinery, a lift to the top of one of the towers, and a high-pressure pump for supplying the fountains, are worked by electricity, each machine having a separate motor.

The principal source of power is a compound "Brünner" horizontal engine worked by steam supplied from two "Babcock and Wilson" boilers. The I50 horse-power thus supplied is transmitted to a steel shaft, where it can be increased up to 300 horse-power by a motor driven by a three-phase alternating current of 3600 volts, the generating plant for which consists of an engine of 100-I 50 horse-power by Wolf, of Magdeburg, and an alternator by Gadda and Co., of Milan. The main shaft can be connected with ten dynamos by different makers, varying from 24 to 300 horse-power, and as these cannot all be used simultaneously, a comparison of their efficiency is possible. Subsidiary electric power is supplied by three steam and two gas engines operating on dynamos, by Brioschi and other makers, and a fine series of accumulators is available for reinforcing the supply of power which, even without this help, is available up to 500 horse-power.

A large search-light exhibited by the Italian navy has been placed at Brunate, a station I 500 feet above sealevel, whence its rays can be flashed over Como and the surrounding district to a distance of many miles.

Technical instruction in electricity is well represented, while the purely physical side comprises exhibits of Röntgen ray apparatus, wireless telegraphy, electrostatic apparatus by A. Dall' Eco and other makers, and so forth.

One room in the exhibition buildings is set apart for the "Cimelii di Volta," under which head are comprised Volta's physical apparatus, original manuscripts of his papers, his letters, diplomas, and many of his personal effects. The greater part of these relics are exhibited by the Reale Istituto Lombardo, under whose auspices the collection was formed by public subscription in the years I86I to 1864 ; for this collection, one of the rooms belonging to the Society at Milan has been specially set apart. Other relics, chiefly personal, are exhibited by Prof. Alessandro Volta and Prof. Zanino Volta. The University of Pavia exhibits several electroscopes, condensers, and similar electrostatic apparatus; and other exhibits are lent by the Como Museum.

The manuscripts include the following :-

(1) A letter to Volta from the French physicist Nollet, dated September 18, 1767 . NO. I 547, vOL. 60] 
(2) A letter from Volta to Prof. Barletti, of Pavia, dated April I8, 1777, containing an anticipation of the electric telegraph. Volta suggests the possibility of connecting Milan and Como with a wire suspended from poles, so that an operator at one end of the line could fire an electric pistol at the other.

(3) A manuscript dated May I4, I782, dealing with animal electricity.

(4) Volta's paper of March 20, I800, announcing his discovery of the electric pile to Sir Joseph Banks, President of the Royal Society.

(5) Volta's monograph on the formation of hail, published about I 806 .

The apparatus exhibited illustrate Volta's inventions of the electrophorus and the "electric pistol," his application of gas to lamps, combined with an electric gaslighting apparatus, his invention of the eudiometer, his researches on the capacity of condensers, his condensing electroscope, his investigations on the law of electrostatic force involving the use of the electric balances and the electrometer, his researches on atmospheric electricity, his studies on the expansion of gases, his first forms of voltaic pile, including the columnar pile represented by several examples, also the "crown of cups," and his early experiments on electrolysis. A number of batteries of Leyden jars, electrostatic machines, and other apparatus used by Volta in his experiments, while not referring to any special advancements in science, go far towards giving us an insight into the thoughts and pursuits of a physicist of a century ago, of whom the people of Como feel justly proud. G. H. BRYAN.

\section{UNITED STATES GEOLOGICAL SURVEY.}

$\mathrm{THE}$ literature of American geology increases at an almost overwhelming rate. We have just received three large volumes containing 2053 pages of letterpress, including Part ii. of the Eighteenth Annual Report of the Survey for 1896-97, being papers chiefly of a theoretical nature; and Part v., the Mineral Resources, in two volumes. We have already called attention in NATURE for May 4 to some of the papers contained in Part ii., of which we received advance copies; these were on "The Triassic Formation of Connecticut," by W. M. Davis, with coloured maps and sections; on the "Geology of the Edwards Plateau and Rio Grande Plain adjacent to Austin and San Antonio, Texas, with reference to the occurrence of underground waters," by R. T. Hill and T. W. Vaughan; and "A Table of the North American Tertiary Horizons, correlated with one another and with those of Western Europe, with annotations," by Mr. William H. Dall.

In addition, this volume contains a report on the "Glaciers of Mount Rainier," by I. C. Russell, with a paper on "The Rocks of Mount Rainier," by G. O. Smith. Associated with the Cascade range in the State of Washington, but of later date and distinct from it both geographically and geologically, are four prominent volcanic mountains, of which one is Mount Rainier, 14,526 feet in height. This mountain is an extinct volcano, but the residual heat of its once molten rocks gives origin to steam-jets, which escape from crevices in the now partially snow-filled craters at the summit. The main mass consists of fragmental andesitic and basaltic materials, with some lava streams; but its outlines have been modified by frost and storms, and deeply sculptured by glaciers. The glaciers are now receding. The scenery around the mountain possesses such great beauty and grandeur that a portion of ground was reserved as a National Park in 1893, and it is now intended to reserve a larger area. Numerous views of the scenery are given.

"The Age of the Franklin White Limestone of Sussex County, New Jersey," is discussed by J. E. Wolff and NO. I 547 , vOL. 6o]
A. H. Brooks. This limestone occurs in the PreCambrian or Archæan highlands of New Jersey, an area largely occupied by gneisses. These schistose rocks have a nearly constant north-east strike and south-east foliation-dip, with a frequent linear parallel structure which is usually "inclined at a moderate angle to the north-east, lying generally in the plane of dip, and is called 'pitch.' "' It is observed that the foliation structure in the limestone is usually parallel to that in the gneiss, and "the pitch structures of the gneiss, white limestone, and associated [magnetite] ore deposits have a general parallelism both in direction and angle." Mr. Wolff regards the pitch-structure as due to primary crystallisation. The authors conclude that the white limestone was deformed, metamorphosed, and partly eroded before the basal member of the Cambrian series was laid down.

"A Geological Sketch of San Clemente Island" is contributed by W. S. T. Smith. This island is the southernmost of a group known as the Channel Islands, which lie off the southern coast of California. It has no permanent human inhabitants except one old man, who has lived there most of the time for the last thirty years. Sheep, cattle and wild goats have been introduced, and there are foxes, lizards and land-shells. The vegetation is limited almost entirely to low shrubbery and herbage. The cactus and "salt-grass" are abundant. The island has a length of nearly twenty-one miles, a maximum width of little over four miles, and an altitude at one point of nearly 2000 feet. It is built up almost entirely of lava flows, with intercalated volcanic breccias and ashes. A detailed account of these is given. Miocene and later sedimentary deposits occupy small areas. The volcanic rocks appear to have been of Miocene age, but older than any of the sedimentary deposits. Attention is drawn to the evidence of faulting which occurred between the close of the Miocene and early Pliocene times, and which has had a marked effect on the physica features of the island. This faulting has continued at intervals ever since.

"The Geology of the Cape Cod District" is described by N. S. Shaler. He discusses the series of geological events which occurred since the beginning of the Cretaceous period in the south-eastern portion of $\mathrm{New}$ England. After tilting and the erosion of the Cretaceous and Tertiary beds, various Pleistocene deposits were laid down, and these in turn became somewhat disturbed. The region, in fact, has evidently been one of remarkable instability. A very full and interesting account is given of the structure of the region and of the glacial and postglacial phenomena, illustrated by numerous views and sections.

"Recent Earth Movement in the Great Lakes Region" is the title of an article by G. K. Gilbert. He points out that although modern movements are of small amount, it is believed that they are of the same kind as the ancient, and that the great changes of the geologic past were effected slowly. His observations now lead to the conclusion that the whole North American lake-region is being lifted on one side or depressed on the other, so that its plane is bodily canted towards the south-southwest, and that the rate of change is such that the two ends of a line Ioo miles long and lying in a south-southwest direction are relatively displaced four-tenths of a foot in Ioo years. The changes are not directly obvious owing to inequalities of rainfall and evaporation, but the mean height of the lake-surfaces has been affected. With reference to the economic bearings of these changes Mr. Gilbert remarks that the modifications are so slow that they may have small importance in engineering works. He observes, however, that it is a matter of greater moment that cities and towns built on lowlands about Lakes Ontario, Erie, Michigan, and Superior will sooner or later feel the encroachment of the advancing 